\title{
Effect of Water/Cement and Aggregate/Cement Ratios on Consistency and Compressive Strength of Concrete Using Volcanic Stone Waste as Aggregates
}

\author{
I Made Alit Karyawan Salain \\ Department of Civil Engineering, Faculty of Engineering, Udayana University, Jimbaran 80361, Bali, Indonesia
}

Received July 14, 2021; Revised August 13, 2021; Accepted September 21, 2021

\section{Cite This Paper in the following Citation Styles}

(a): [1] I Made Alit Karyawan Salain, "Effect of Water/Cement and Aggregate/Cement Ratios on Consistency and Compressive Strength of Concrete Using Volcanic Stone Waste as Aggregates," Civil Engineering and Architecture, Vol. 9, No. 6, pp. 1900-1908, 2021. DOI: 10.13189/cea.2021.090621.

(b): I Made Alit Karyawan Salain (2021). Effect of Water/Cement and Aggregate/Cement Ratios on Consistency and Compressive Strength of Concrete Using Volcanic Stone Waste as Aggregates. Civil Engineering and Architecture, 9(6), 1900-1908. DOI: 10.13189/cea.2021.090621.

Copyright $\bigcirc 2021$ by authors, all rights reserved. Authors agree that this article remains permanently open access under the terms of the Creative Commons Attribution License 4.0 International License

\begin{abstract}
This study investigates the effect of water cement $(\mathrm{w} / \mathrm{c})$ ratio and aggregate cement $(\mathrm{a} / \mathrm{c})$ ratio on consistency and compressive strength of concrete made by using volcanic stone waste aggregates. A total of 12 (twelve) concrete mixtures were made by varying $\mathrm{w} / \mathrm{c}$ ratio and a/c ratio. Portland pozzolan cement was used as a hydraulic binder while volcanic stone wastes with a maximum diameter of $40 \mathrm{~mm}$ granules were used as fine aggregate and coarse aggregate. The consistency test, which is expressed in term of slump, was carried out for fresh concrete, while the compressive strength test, for each concrete mixture, was realized at the age of 28 days using 5 (five) cubical specimens measuring $150 \times 150 \times 150 \mathrm{~mm}$. The results of this study show that slump increases and compressive strength decreases with increasing $\mathrm{w} / \mathrm{c}$ ratio for a constant $\mathrm{a} / \mathrm{c}$ ratio. Slump decreases and compressive strength slightly increases with increasing $\mathrm{a} / \mathrm{c}$ ratio for a constant $\mathrm{w} / \mathrm{c}$ ratio. The decrease in slump and the increase in compressive strength with increasing $\mathrm{a} / \mathrm{c}$ ratio for a constant $\mathrm{w} / \mathrm{c}$ ratio is more clearly noted for a w/c ratio more than 0.5 . Compressive strength decreases proportionally with increasing slump due to the increase in w/c ratio. This decrease tends to be sharper in mixture with lower $\mathrm{a} / \mathrm{c}$ ratio.
\end{abstract}

Keywords Volcanic Stone Waste, Water Cement Ratio, Aggregate Cement Ratio, Consistency, Compressive Strength

\section{Introduction}

Concrete as a construction material is currently at the top in the number of uses in the world. In the future, this condition will continue to meet the needs of the world's population for infrastructure. This can be observed from a report submitted by Chatham House which states that the production of Portland cement, as a hydraulic binder in the concrete industry, which currently has reached more than 4 billion tons per year will increase by 2050 to more than 5 billion tons per year [1]. The widely use of concrete for infrastructure construction in the world makes studies related to this construction material remain an interesting issue for researchers and industries in order to increase knowledge of its properties and performance so that its utilization in the world of construction services becomes more popular. In practice, strength, especially compressive strength, is the primary property of concrete that is of greatest concern to designers and engineers. This is related to the relative ease of carrying out strength test compared to other concrete property tests. In addition, many other concrete properties, such as modulus of elasticity and tensile strength, can be approximated by knowing the compressive strength data. In addition to compressive strength, consistency is an important 
property of fresh concrete to be considered in concrete applications. Good concrete consistency will facilitate the compaction process of fresh concrete to produce high concrete density so that maximum concrete strength is obtained.

It is well known that two of the main factors that affect the performance of both fresh and hard concrete are the characteristics and proportions of the constituent materials: water, cement, fine and coarse aggregates [2-4]. Researches related to the effect of water cement $(\mathrm{w} / \mathrm{c})$ ratio as well as aggregate cement $(\mathrm{a} / \mathrm{c})$ ratio in concrete mixture on the properties of fresh and hard concrete have been previously realized. The result of extensive research has shown that the compressive strength of concrete decreases with increasing $\mathrm{w} / \mathrm{c}$ ratio, so long as the mixture is workable [5]. Another study found that concrete mixtures with higher $\mathrm{a} / \mathrm{c}$ ratio, for a constant $\mathrm{w} / \mathrm{c}$ ratio, resulted in higher compressive strength [6]. Furthermore, it was reported that for a constant $\mathrm{w} / \mathrm{c}$ ratio of 0.6 , the compressive strength of concrete at 7 days decreased by about $12 \%$ when cement content and coarse/fine aggregate proportion were progressively increased to produce a slump of 50 to $150 \mathrm{~mm}$ [3]. The increase in slump and compaction factor of concrete were observed when cement content increased and the aggregate content as well as w/c ratio decreased [7,8]. It was found next that the compressive strength of concrete, for a constant cement content, could be increased by slightly increasing or decreasing the ratio of fine aggregate to coarse aggregate relative to a control mixture [9]. In a study concerning lightweight concrete, it was reported that its compressive strength increased when a/c ratio decreased [10]. The results of those studies clearly show that fresh and hard concrete performance are influenced by relative content of water, cement, fine and coarse aggregates used in concrete mixture.

On the other hand, in Bali, Indonesia, there is a type of stone formed from the cooling process of volcanic lava. This type of stone, hereinafter referred to as volcanic stone, is dark in color, blackish gray, and has a lower density than basalt but higher than pumice. In Bali, this type of stone is generally used as handmade ornaments for traditional Balinese buildings. However, the rest of this stone processing, in the form of pieces of stone, is usually disposed of around the craftsman's work site into waste or used as backfill. If this condition continues, it will certainly disturb the environment in the future. In addition, the waste will not have significant technical and economic value. One of the efforts that can be done to overcome this problem and to increase simultaneously their technical and economic value is to process this waste into aggregate in the manufacture of concrete [11]. In other country, the use of Cameroonian coarse volcanic scoria as sand in Portland cement mortar [12] as well as the potential utilization of volcanic rock waste from southern Brazil as a natural soil fertilizer [13] have been studied.

It is realized that a more in-depth study of this waste is needed to improve understanding of its properties as aggregates in the manufacture of concrete. If the use of waste as aggregate can produce performance equivalent to the use of normal aggregates, it is expected that natural stone mining can be reduced so that environmental sustainability can be maintained. Related to this, it will be investigated the effect of both $\mathrm{w} / \mathrm{c}$ ratio and $\mathrm{a} / \mathrm{c}$ ratio on consistency and compressive strength of concrete made by using volcanic stone waste as fine and coarse aggregates. This is interesting considering that the properties of fresh and hard concrete depend also on the type and origin of the aggregates used in the concrete mixture [14,15]. In this study, consistency is measured in terms of slump on fresh concrete while compressive strength is determined on the 28 day old specimens. The results obtained are expected to increase knowledge in the field of concrete technology, especially related to the effect of w/c ratio and $\mathrm{a} / \mathrm{c}$ ratio on consistency and compressive strength of concrete using volcanic stone waste aggregates.

\section{Materials and Methods}

The materials used to make concrete in this study consisted of water, cement, fine aggregate and coarse aggregate. Water was obtained from municipal tap water network in the Structure and Materials Laboratory, Civil Engineering Department, Faculty of Engineering, Udayana University. For hydraulic binder, it was used Portland pozzolan cement (PPC) which was purchased from a building material store. This hydraulic binder complies with the provisions of SNI 15-0302-2004 concerning PPC [16]. This Indonesian standard refers to ASTM C 595-03 [17]. Fine aggregate (FA) and coarse aggregate $(\mathrm{CA})$ were volcanic stone waste being residual of volcanic stone processing for producing traditional Balinese buildings handmade ornaments.

The waste obtained from the craftsman's work area was prepared before being used as aggregate in the concrete mixture. First, the stone waste was crushed manually using a hammer to obtain grains with a maximum diameter of $40 \mathrm{~mm}$. And then, the grains were sorted according to the FA category i.e. grains with a size of 0.15 $\mathrm{mm}-4.0 \mathrm{~mm}$ and the CA category i.e. grains with a size of $4.0 \mathrm{~mm}-40.0 \mathrm{~mm}$. The distribution of FA and CA grains were designed to meet zone 2 for FA and grains with a maximum diameter of $40 \mathrm{~mm}$ for CA, according to SNI 03-2834-2000 concerning procedures for designing concrete mixtures [18]. Before using these aggregates, their physical properties were examined. Table 1 shows their physical properties while Figures 1 and 2 present their grading design. 
Table 1. Physical properties of fine aggregate and coarse aggregate

\begin{tabular}{|c|c|c|c|}
\hline No. & Physical Properties & Fine Aggregate & Coarse Aggregate \\
\hline 1. & Unit weight $\left(\mathrm{g} / \mathrm{cm}^{3}\right)$ & 1.4 & 1.1 \\
\hline 2. & Specific weight SSD & 2.5 & 2.0 \\
\hline 3. & Absorption (\%) & 1.3 & 5.9 \\
\hline 4. & Abrasion $(\%)$ & - & 28.7 \\
\hline
\end{tabular}

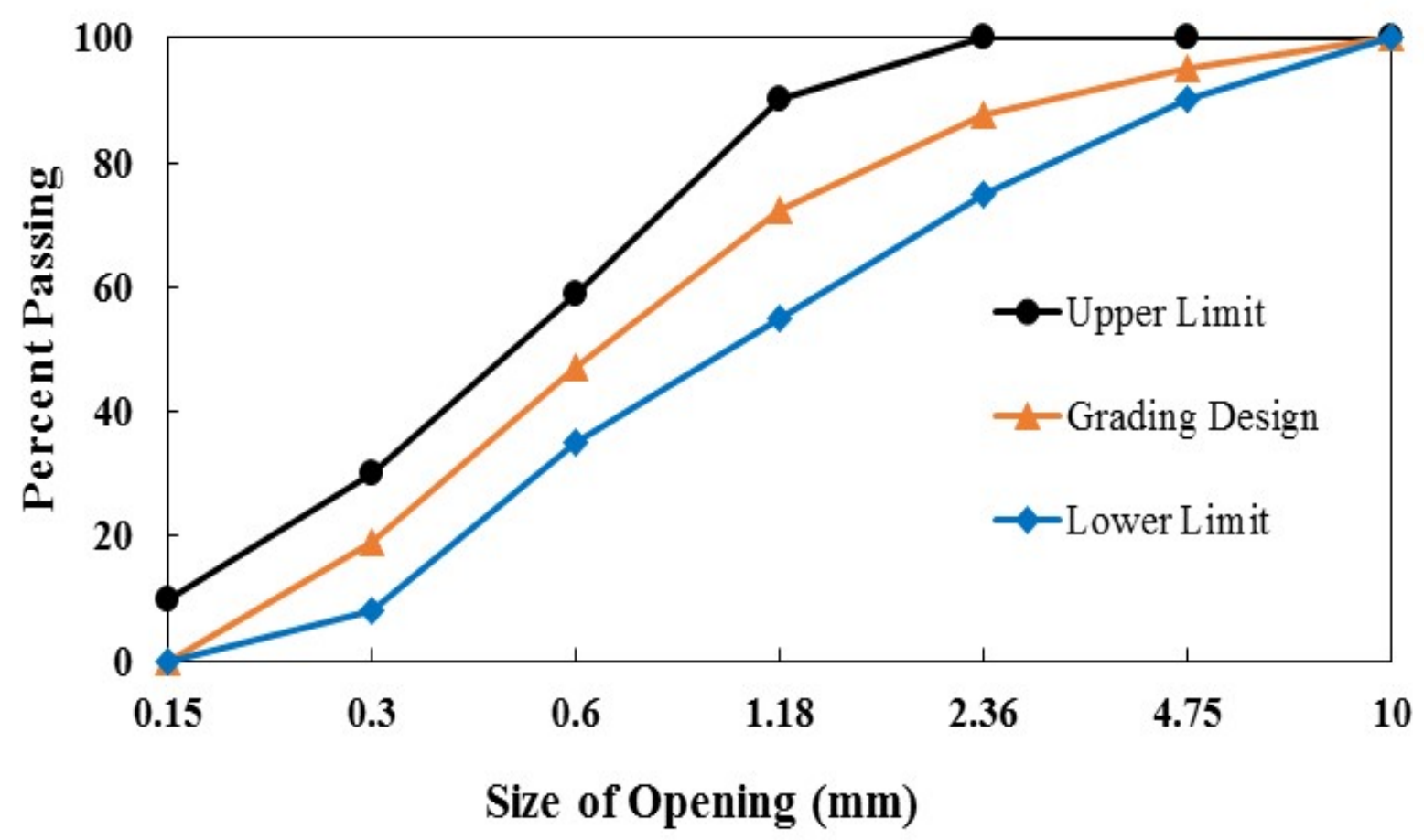

Figure 1. Grading curve for fine aggregate with SNI 03-2834-2000 grading limits

It was determined to study 3 (three) proportions of concrete mixture, by weight ratio, between PPC, FA, and CA which resulted in 3 (three) variations of a/c ratio, namely 4.0, 5.0, and 6.0. To mixing each concrete mixture proportion, 4 (four) variations of the $\mathrm{w} / \mathrm{c}$ ratio were used in the range of 0.4 to 0.9 . Thus in total there were 12 (twelve) variations of concrete mixture as shown in Table 2. It is necessary to use a different range of w/c ratios for each mixture proportion in order to ensure that the concrete is workable.

Table 2. Proportion of concrete mixture

\begin{tabular}{|c|c|c|c|}
\hline Mixture & Proportion PPC : FA : CA & w/c Ratio & a/c Ratio \\
\hline M1 & $1.0: 1.5: 2.5$ & 0.4 & 4.0 \\
\hline M2 & $1.0: 1.5: 2.5$ & 0.5 & 4.0 \\
\hline M3 & $1.0: 1.5: 2.5$ & 0.6 & 4.0 \\
\hline M4 & $1.0: 1.5: 2.5$ & 0.7 & 4.0 \\
\hline M5 & $1.0: 2.0: 3.0$ & 0.5 & 5.0 \\
\hline M6 & $1.0: 2.0: 3.0$ & 0.7 & 5.0 \\
\hline M7 & $1.0: 2.0: 3.0$ & 0.8 & 5.0 \\
\hline M8 & $1.0: 2.0: 3.0$ & 0.6 & 5.0 \\
\hline M9 & $1.0: 2.5: 3.5$ & 0.7 & 6.0 \\
\hline M10 & $1.0: 2.5: 3.5$ & 0.8 & 6.0 \\
\hline M11 & $1.0: 2.5: 3.5$ & 0.9 & 6.0 \\
\hline M12 & $1.0: 2.5: 3.5$ & & 6.0 \\
\hline
\end{tabular}




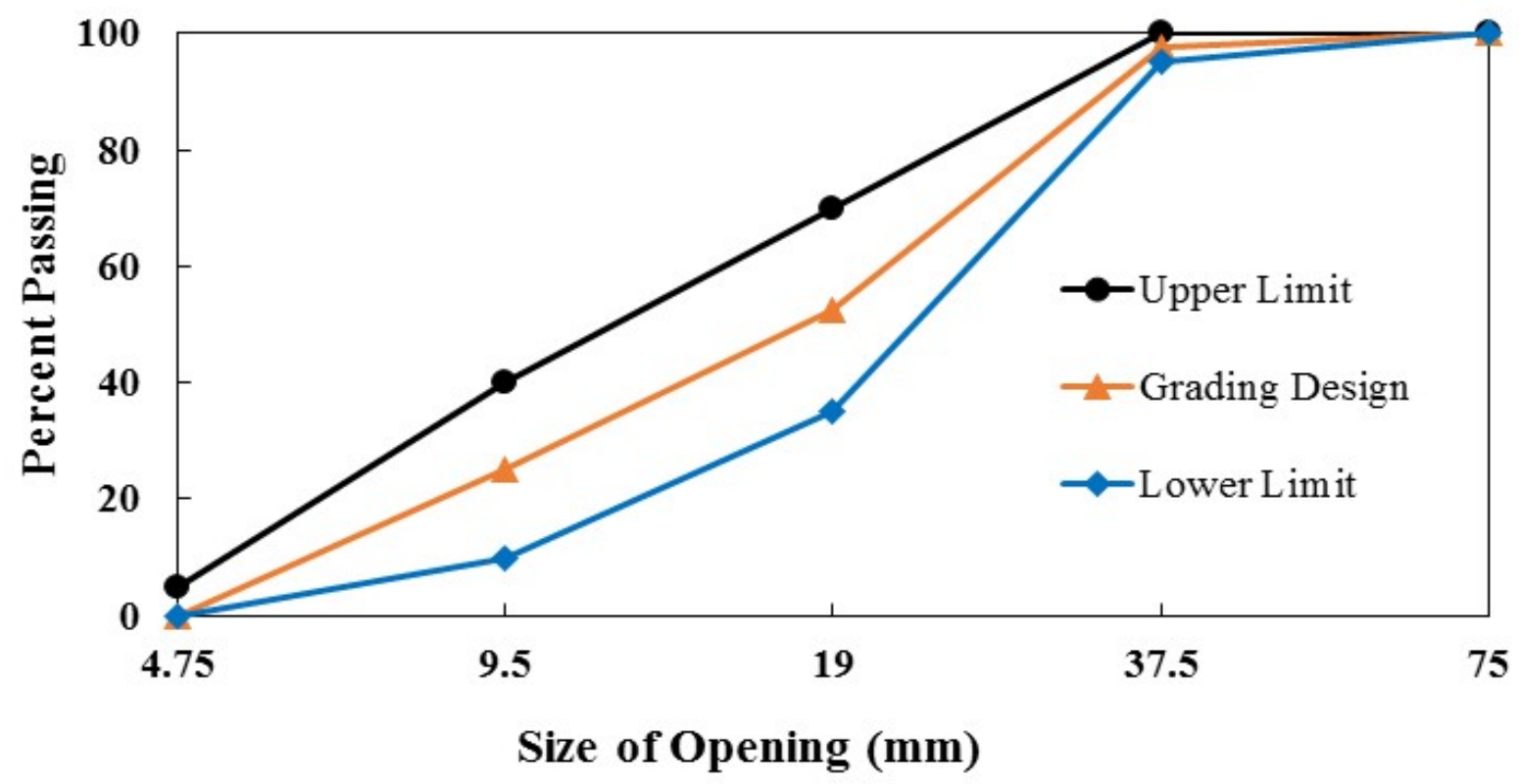

Figure 2. Grading curve for coarse aggregate with SNI 03-2834-2000 grading limits

Mixing of the concrete mixture was realized by using a mixer and before being mixed the aggregate was prepared in Saturated Surface Dry (SSD) condition. After mixing, slump test was carried out to determine consistency of the fresh concrete mixture by using slump test equipment. And then, cubical specimens sizing of $150 \times 150 \times 150$ $\mathrm{mm}$ were casted. The specimens were prepared in accordance with SNI 2493-2011 concerning procedures for casting and maintaining concrete specimens in the laboratory [19]. This Indonesian standard refers to ASTM C 192/C 192M-95 [20]. After casting, the specimen were kept in molds for 24 hours and then demolded and cured in water until used for compressive strength test. For each mixture proportion, 5 (five) specimens were made for the strength test at the age of 28 days. The compressive strength test was carried out according to SNI 1974-2011 concerning test method for compressive strength of concrete [21] using a compression test machine with a capacity of $2000 \mathrm{kN}$. Figure 3 presents the process of casting and curing of the specimens as well as measuring the consistency and the compressive strength of concrete.
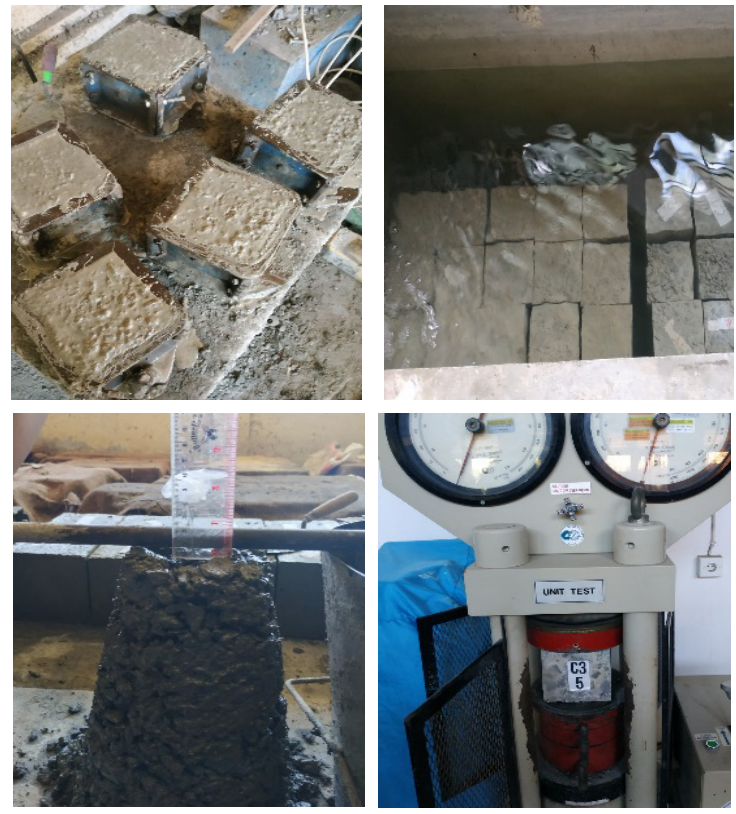

Figure 3. Casting and curing of specimens and measuring consistency and compressive strength of concrete 


\section{Results}

\subsection{Slump}

The results of consistency test of concrete mixture for each proportion, which were carried out through slump test, are shown in Table 3. In this table it is presented the average result of 5 (five) measurements of slump, standard deviation (s) and coefficient of variance (CV). Based on the CV for each mixture, it can be considered that all of the mixture were well mixed and homogenous.

From this data, Figure 4 was then made illustrating changes in slump based on variations in the proportion of the mixture obtained by varying the $\mathrm{w} / \mathrm{c}$ ratio and $\mathrm{a} / \mathrm{c}$ ratio.

Table 3. Slump, standard deviation and coefficient of variance

\begin{tabular}{|c|c|c|c|}
\hline Mixture & Slump (mm) & $\mathbf{s ~ ( m m ) ~}$ & CV (\%) \\
\hline M1 & 5 & 0.2 & 4.6 \\
\hline M2 & 12 & 0.7 & 5.9 \\
\hline M3 & 125 & 7.0 & 5.5 \\
\hline M4 & 175 & 9.4 & 5.3 \\
\hline M5 & 10 & 0.5 & 5.4 \\
\hline M6 & 45 & 2.5 & 5.7 \\
\hline M7 & 145 & 7.9 & 5.5 \\
\hline M8 & 185 & 9.7 & 5.2 \\
\hline M9 & 12 & 0.7 & 5.5 \\
\hline M10 & 80 & 4.6 & 5.7 \\
\hline M1 & 105 & 6.1 & 5.8 \\
\hline M12 & 157 & 8.4 & 5.4 \\
\hline
\end{tabular}

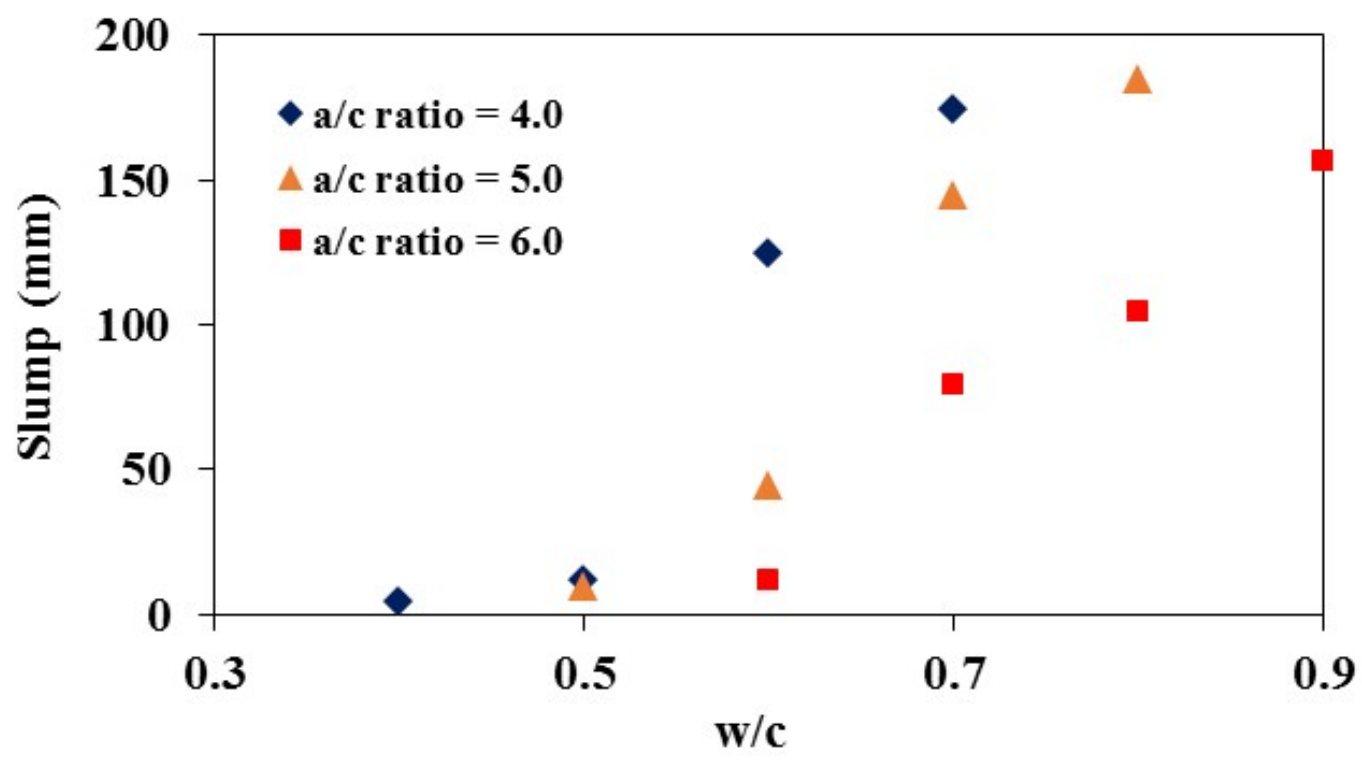

Figure 4. Slump vs w/c for various a/c

From Table 3 and Figure 4 it can be clearly seen that slump varies due to changes in $\mathrm{w} / \mathrm{c}$ ratio and $\mathrm{a} / \mathrm{c}$ ratio. For the mixture with $\mathrm{a} / \mathrm{c}$ ratio of 4.0 and $\mathrm{w} / \mathrm{c}$ ratio increased from 0.4 to 0.7 , slump increases from $5 \mathrm{~mm}$ to $175 \mathrm{~mm}$. In the mixture with a/c ratio of 5.0 and $\mathrm{w} / \mathrm{c}$ ratio increased from 0.5 to 0.8 , it increases from $10 \mathrm{~mm}$ to $185 \mathrm{~mm}$ and for the mixture with $\mathrm{a} / \mathrm{c}$ ratio of 6.0 and $\mathrm{w} / \mathrm{c}$ ratio increased from 0.6 to 0.9 , it increases from $12 \mathrm{~mm}$ to 157 $\mathrm{mm}$. This indicates that, in general, for mixtures with constant $\mathrm{a} / \mathrm{c}$, slump increases with increasing $\mathrm{w} / \mathrm{c}$ ratio. This is in accordance with what is mentioned in the literature [2-4]. It is then observed that a greater increase 
in slump with increasing $\mathrm{w} / \mathrm{c}$ ratio tends to occur in mixtures with lower a/c ratio.

On the other hand, for mixtures with a constant $\mathrm{w} / \mathrm{c}$ ratio, it is seen that slump decreases with increasing $\mathrm{a} / \mathrm{c}$ ratio. The decrease in slump with increasing $\mathrm{a} / \mathrm{c}$ ratio is more clearly seen when the $\mathrm{w} / \mathrm{c}$ ratio is more than 0.5 .

\subsection{Compressive Strength}

The results of the compressive strength test of the specimens at the age of 28 days for each mixture proportion are shown in Table 4. In this table it is presented the average result of 5 (five) specimens, standard deviation (s) and coefficient of variance (CV). As in the case of slump and according to the CV of each mixture, it can also be considered here that all of the mixture were well mixed and homogenous. By using this data, Figure 5 was then made illustrating changes in compressive strength based on variations in the proportion of the mixture.

Referring to Table 4 and Figure 5, it can be seen that the variation in compressive strength follows changes in $\mathrm{w} / \mathrm{c}$ ratio and $\mathrm{a} / \mathrm{c}$ ratio. In concrete with $\mathrm{a} / \mathrm{c}$ ratio of 4.0 and $\mathrm{w} / \mathrm{c}$ ratio increased from 0.4 to 0.7 , the compressive strength reduces from $42 \mathrm{MPa}$ to $15 \mathrm{MPa}$. For concrete with a/c ratio of 5.0 and the w/c ratio increased from 0.5 to 0.8 , it reduces from $31 \mathrm{MPa}$ to $10 \mathrm{MPa}$ and for concrete with a/c ratio of 6.0 and the w/c ratio increased from 0.6 to 0.9 , it reduces from $24 \mathrm{MPa}$ to $9 \mathrm{MPa}$. In general, these results indicate that for mixtures with constant $\mathrm{a} / \mathrm{c}$ ratio, the compressive strength of concrete decreases with increasing $\mathrm{w} / \mathrm{c}$ ratio. This is in accordance with the results shown in previous study [6]. In addition, it is also observed that the decrease in the compressive strength of concrete tends to be sharper in the mixture with lower $\mathrm{a} / \mathrm{c}$ ratio.

Table 4. Compressive strength, standard deviation and coefficient of variance

\begin{tabular}{|c|c|c|c|}
\hline Mixture & Compressive Strength (MPa) & $\begin{array}{c}\text { S } \\
\text { (MPa) }\end{array}$ & $\begin{array}{c}\text { CV } \\
(\%)\end{array}$ \\
\hline M1 & 42 & 1.8 & 4.2 \\
\hline M2 & 35 & 1.5 & 4.4 \\
\hline M3 & 21 & 1.2 & 5.7 \\
\hline M4 & 15 & 0.4 & 2.8 \\
\hline M5 & 31 & 0.9 & 5.8 \\
\hline M6 & 22 & 1.2 & 2.4 \\
\hline M7 & 17 & 0.4 & 5.7 \\
\hline M8 & 10 & 0.6 & 4.7 \\
\hline M9 & 24 & 1.1 & 2.2 \\
\hline M10 & 18 & 0.4 & 2.4 \\
\hline M11 & 11 & 0.3 & 5.0 \\
\hline M12 & 9 & 0.5 & 5.5 \\
\hline
\end{tabular}

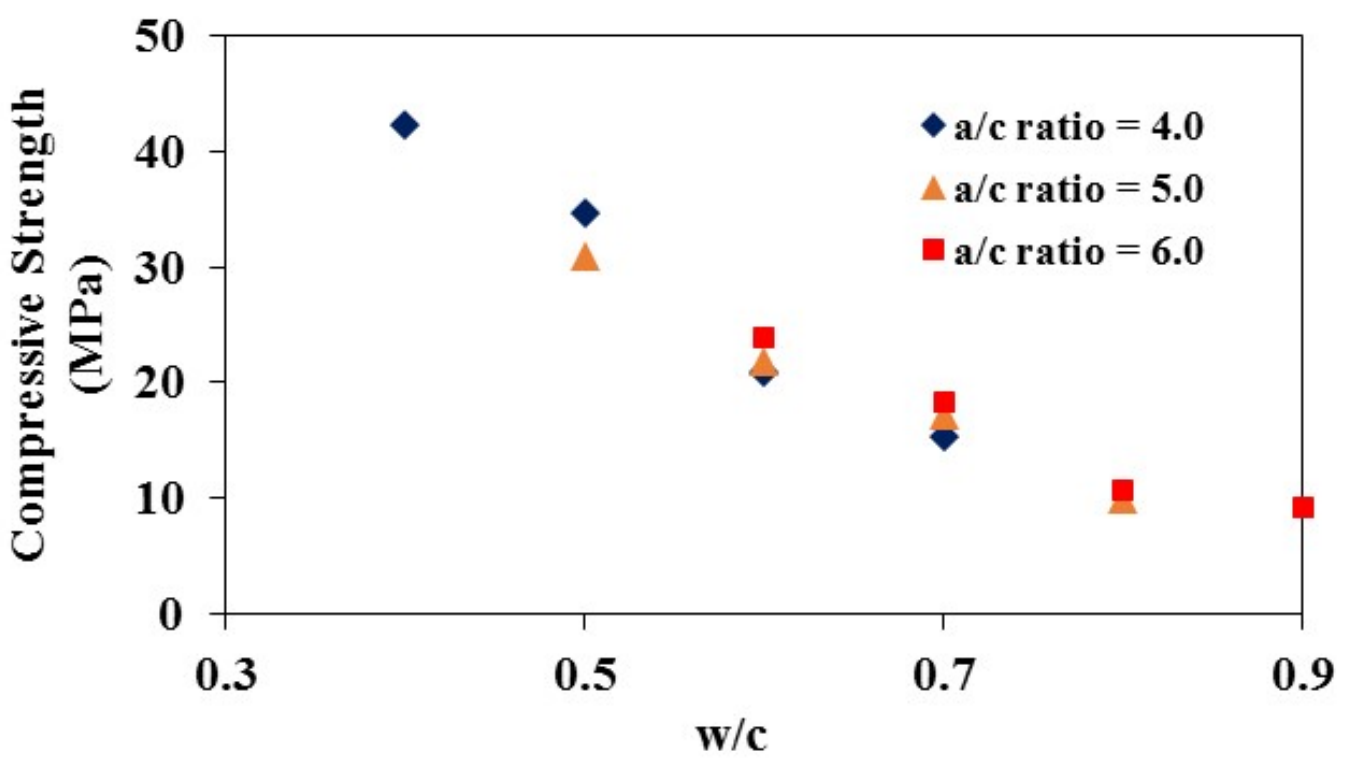

Figure 5. Compressive strength vs w/c for various a/c 
On the other hand, it can be seen that, for concrete mixtures with a constant w/c ratio, the compressive strength tends to increase slightly with increasing a/c ratio. This phenomenon is also mentioned in other study [6]. However, it is only clearly seen in concrete mixtures with a w/c ratio more than 0.5 .

\section{Discussion}

The test results on the slump and compressive strength of concrete mixtures with variations in $w / c$ ratio and $a / c$ ratio clearly show the effect of each of these factors on the properties of both fresh and hard concrete. Regarding consistency of the concrete mixture as expressed by slump, it was noted that slump increases with increasing $\mathrm{w} / \mathrm{c}$ ratio for a constant $\mathrm{a} / \mathrm{c}$ ratio. This is related to the increase in the amount of water used to mixing the concrete which increases lubrication of the aggregate grains so that the internal friction between the grains is reduced. Therefore, the flow of the concrete mixture becomes easier which results in a higher slump. With lower a/c ratio, slump increases more sharply when $\mathrm{w} / \mathrm{c}$ ratio increases. This phenomenon is related to the use of cement in the mixture which is relatively more than the aggregate so that more paste is formed than in the mixture with a higher $\mathrm{a} / \mathrm{c}$ ratio. Furthermore, with lower a/c ratio, the surface area of the aggregates decreases. Consequently, the flow of the mixture becomes easier so that slump increases sharply.

On the other hand, it was found that slump decreases with increasing $\mathrm{a} / \mathrm{c}$ ratio at a constant $\mathrm{w} / \mathrm{c}$ ratio. This is related to the increase in the amount of aggregate while the amount of cement decreases in the mixture. As the amount of aggregate increases, the surface area of the aggregate increases while the amount of water, as a function of the amount of cement, decreases even though the w/c remains constant. This condition causes the mixture to become drier and the friction between the aggregate grains increases so that the flow of the mixture becomes difficult and finally slump of the mixture reduces. This phenomenon is clearly seen when w/c ratio is above 0.5 related to the amount of more water used for mixing so that change in consistency becomes easier to observe. However, in mixtures with a ratio of $\mathrm{w} / \mathrm{c}=0.5, \mathrm{M} 2(\mathrm{a} / \mathrm{c}=$ 4.0) and M5 $(\mathrm{a} / \mathrm{c}=5.0)$, this phenomenon can also be observed but with very small slump changes. Therefore, it is important to underline that the slump in the mixture depends on the degree of variation in the $\mathrm{w} / \mathrm{c}$ and $\mathrm{a} / \mathrm{c}$ ratios as well as the shape and surface texture of the aggregate used. The aggregates used in this study which were produced by manual crushing have an angular and a rough texture. It seems that the relatively low slumps measured on M1, M2, M5, and M9 mixtures are strongly influenced by these conditions.

It is well known that the proportion of the concrete mixture affects the compressive strength of concrete. The results of this study showed that the compressive strength of concrete decreases with increasing w/c ratio, for a constant $\mathrm{a} / \mathrm{c}$ ratio. This phenomenon is caused by increasing porosity with increase in the amount of water used to mixing the concrete [2-4]. It is well known that to achieve complete hydration, cement requires water, depending on its fineness, about $25 \%-30 \%$ by weight [22] The use of water in concrete other than for cement hydration process is also to lubricate the aggregate so that the concrete is more workable. Excess water that is not needed for the hydration process, in the course of time, will be expelled and will leave pores in hard concrete. The more water is used to mixing concrete, the more pores are formed due to excess water so that the density of concrete decreases and consequently its strength also decreases. In addition, the excess water used in the mixture is also vulnerable in terms of the durability of the concrete [2-4]. This is related to the increase in the permeability of the concrete due to the formation of more pores which in turn facilitates chemical attacks that cause concrete damage. Thus, in fact, only a sufficient amount of water is needed for concrete mixing. However, the mixing water must be sufficient for cement hydration and simultaneously to produce a workable concrete mixture in order to obtain maximum strength.

The trend towards a sharper decrease in compressive strength in mixtures with lower a/c ratio along with an increase in w/c ratio is related to the amount of cement in the mixture being relatively higher than the amount of aggregate. As w/c ratio increases, relatively more water is used to mixing the concrete. This condition resulted in more residual water in the mixture with lower a/c ratio compared to higher a/c ratio. This condition causes the pores formed in the concrete increase more so that the compressive strength decreases sharply.

Moreover, it is interesting to note that the compressive strength tends to increase slightly with increasing a/c ratio for concrete mixtures with a constant $w / c$ ratio. This could be related to the porosity formed in the concrete. In a mixture with a higher $\mathrm{a} / \mathrm{c}$ ratio, the use of cement is relatively less compared to a mixture with a lower a/c ratio, but still within sufficient limits to bind well the aggregate to form a solid mass. With less cement, less mixing water is used for a constant $\mathrm{w} / \mathrm{c}$ ratio and consequently less excess water. This condition causes the pores formed decrease so that the resulting compressive strength is slightly higher than the mixture with a lower $\mathrm{a} / \mathrm{c}$. However, this phenomenon only occurs in concrete mixtures with a w/c ratio more than 0.5 . It seems that the use of a higher $\mathrm{a} / \mathrm{c}$ ratio under this condition has a beneficial effect on the development of compressive strength associated with the reduction of pores formed in the concrete.

Furthermore, in Figure 6 it is presented changes in compressive strength related to changes in slump due to variation of $\mathrm{w} / \mathrm{c}$ and $\mathrm{a} / \mathrm{c}$ ratios. 


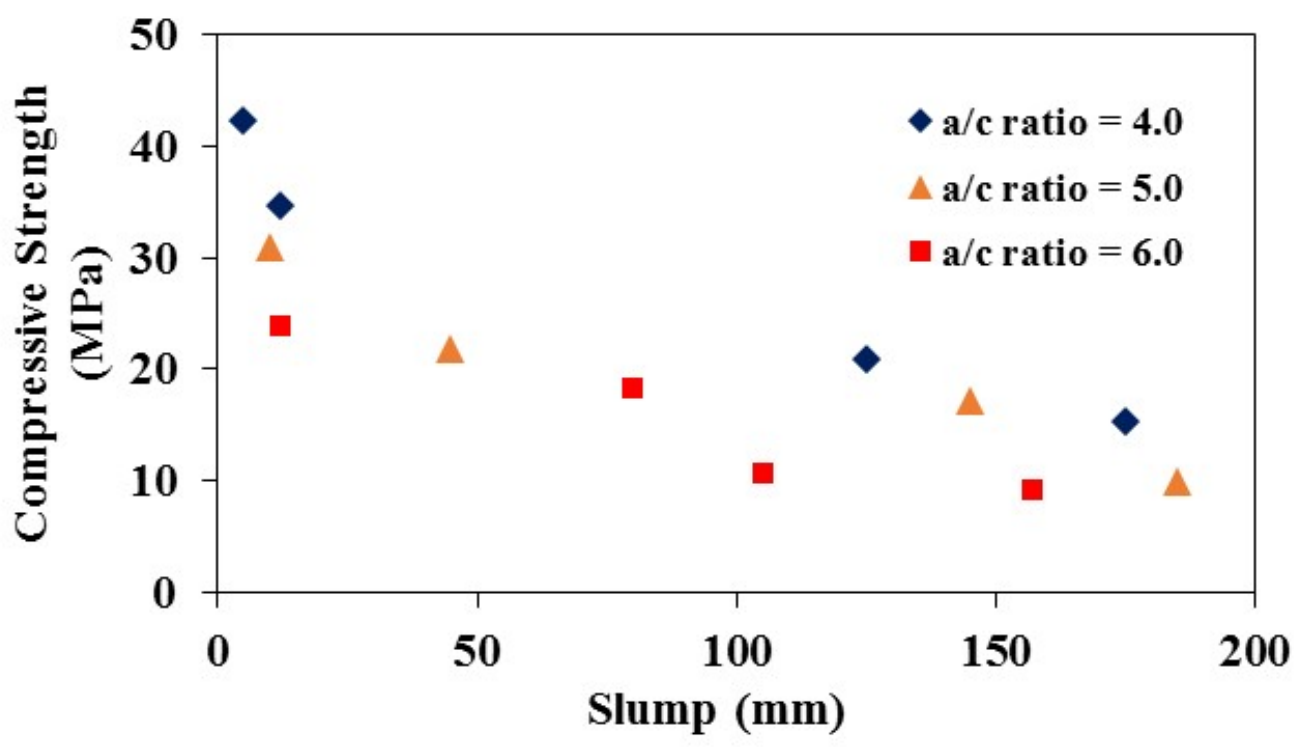

Figure 6. Compressive strength vs slump for various a/c

From Figure 6 it can be seen that the compressive strength decreases proportionally with the increase of slump, for all variations of $\mathrm{a} / \mathrm{c}$ ratio. The increase of slump in the concrete mixture is caused by the increase of mixing water which is represented by the increase of $w / c$ ratio. The use of a higher amount of water, as previously stated, for a constant mixture proportion, implies the formation of more pores in concrete due to the release of excess water than required for the hydration process. With higher porosity, the compressive strength produced by a concrete mixture is reduced.

Furthermore, it can be observed that there is a sharper decrease in compressive strength when slump increase in concrete with lower a/c ratio. As described previously, this phenomenon is related to the relatively higher amount of cement than aggregate used in concrete with lower a/c ratio. When w/c ratio increases, slump increases because more water is used to mixing the concrete. This condition causes more pores formed due to excess water in the mixture with lower a/c ratio compared to higher a/c ratio resulting in a sharp reduction in the compressive strength.

Finally, it is interesting to note that waste volcanic stone whose properties are lower than natural stone after being formed into aggregates can be used to produce structural concrete based on SNI 2847-2019 [23]. According to this Indonesian standard which refers to ACI $318 \mathrm{M}-14 / 318 \mathrm{RM}-14$ [24], the required concrete compressive strength is a minimum of $17 \mathrm{MPa}$ for general use and a minimum of $21 \mathrm{MPa}$ for special moment resisting frame systems and special structural walls. Therefore, from the point of view strength only, a mixture of M7 and M10 could be used for the former while M1, M2, M3, M5, M6, and M9 could be used for the latter.

\section{Conclusions}

From the results obtained from this study and the discussion carried out, it can be concluded as follows.

- The consistency of the concrete mixture which is indicated by slump, decreases with increasing a/c ratio for a constant $w / c$ ratio and increases with increasing $\mathrm{w} / \mathrm{c}$ ratio for a constant $\mathrm{a} / \mathrm{c}$ ratio.

- The compressive strength of concrete decreases with increasing $\mathrm{w} / \mathrm{c}$ ratio for a constant $\mathrm{a} / \mathrm{c}$ ratio and increases slightly with increasing $\mathrm{a} / \mathrm{c}$ ratio for $\mathrm{a}$ constant $\mathrm{w} / \mathrm{c}$ ratio.

- The decrease in slump and the increase in compressive strength with increasing $\mathrm{a} / \mathrm{c}$ ratio for a constant $\mathrm{w} / \mathrm{c}$ ratio is more clearly seen for a $\mathrm{w} / \mathrm{c}$ ratio more than 0.5 .

- The compressive strength decreases proportionally with the increase in slump which is caused by the increase in $\mathrm{w} / \mathrm{c}$ ratio.

- The decrease in compressive strength due to the increase in slump tends to be sharper in the mixture with lower a/c ratio.

\section{Acknowledgments}

The author expresses his sincere gratitude to the Leaders of Udayana University through the Udayana University LPPM who provided financial support for this research grant and to all who have contributed to the implementation of this study.

\section{REFERENCES}

[1] Lehne, J. and Preston, F., "Making Concrete Change: Innovation in Low-carbon Cement and Concrete," Chatam House Report, The Royal Institute of International Affairs, London, 2018, pp. 1-122. 
[2] Druex, G. et Festa, J., "Nouveau guide du béton," 7éme édition, Eyrolles, Paris, 1995, pp. 1-318.

[3] Mehta, P. K., "Concrete: structure, properties and materials," 1st edition, Prentice Hall Inc., New Jersey, 1995, pp. 1-440.

[4] Neville, M. and Brooks, J.J., "Concrete Technology," Updated, Longman Singapore Publishers Pte Ltd, 1998, pp. $1-420$.

[5] Abrams, D. A., "Design of Concrete Mixtures," Bulletin 1 Structural Materials Research Laboratory, Lewis Institute, Chicago, 1919, pp. 1-20.

[6] Singh, B. G., "Specific Surface of Aggregates Related to Compressive and Flexural Strength of Concrete," Journal American Concrete Institute, vol. 54, pp. 897-907, 1958.

[7] Marar, K. dan Eren, Ö., "Effect of cement content and water/cement ratio on fresh concrete properties without admixtures," International Journal of the Physical Sciences, vol. 6, no. 24, pp. 5752-5765, 2011. DOI: 10.5897/IJPS11.188

[8] Okah, J. C. dan Amos, E. N. J., "Effect of Aggregate/Cement and Water/Cement Ratios on Concrete Workability," IIARD International Journal of Geography and Environmental Management, vol. 4, no. 4, pp. 89-99, 2018.

[9] Okonkwo, V. O. dan Arinze, E. E., "A Study of the Effect of Aggregate Proportioning on Concrete Properties," American Journal of Engineering Research, vol. 7, no. 4, pp. 61-67, 2018.

[10] Gündüz, L., "The effects of pumice aggregate/cement ratios on the low-strength concrete properties," Construction and Building Materials, vol. 22, no. 5, pp. 721-728, 2008. DOI: 10.1016/j.conbuildmat.2007.01.030

[11] Salain, I M. A. K., Ciawi, Y., Nadiasa, M, dan Sutapa, A. A. G., "Performance of Black Stone Waste as Coarse Aggregate in Concrete Production," International Journal of Engineering and Technology, vol. 11, no. 1, pp. 1-5, 2019. DOI: $10.21817 /$ ijet/2019/v11i1/191101002

[12] Tchamdjou, W. H. J., Grigoletto, S., Michel, F., Courard, L, Abidi, M. L., and Cherradi, T., "An investigation on the use of coarse volcanic scoria as sand in Portland cement mortar," Case Studies in Construction Materials, vol. 7, pp. 191-206, 2017. http://dx.doi.org/10.1016/j.cscm.2017.07.005

[13] Ramos, C. G., Querol. X, Dalmora, A. C., De Jesus Pires, K. C., Schneider, I. A. H., Oliveira, L. F. S., and Kautzmann, R.
M., "Evaluation of the potential of volcanic rock waste from southern Brazil as a natural soil fertilizer," Journal of Cleaner Production, vol. 142, no. 4, pp. 2700-2706, 2017. https://doi.org/10.1016/j.jclepro.2016.11.006

[14] Kaplan, M. F., "The effects of the properties of coarse aggregates on the workability of concrete," Magazine of Concrete Research, vol. 10, no. 29, pp. 63-74, 2015.

[15] Osuská, L. and Hela, R., "The Impact of Different Aggregate Types and Its Composition on Resulting Concrete Properties Representing the Water Impermeability Level of Concrete for the Construction of White Boxes," Civil Engineering and Architecture, vol. 8, no. 2, pp. 39-45, 2020. DOI: $10.13189 /$ cea.2020.080201

[16] Badan Standarisasi Nasional, "Standar Nasional Indonesia Untuk Semen Portland Pozzolan (In Indonesian): SNI 15-0302-2004,” BSN, Indonesia, 2004, pp. 1-5.

[17] ASTM C 595-03, "Standard Specification for Blended Hydraulic Cements," American Society for Testing and Materials, USA.

[18] Badan Standarisasi Nasional, "Standar Nasional Indonesia Untuk Tata Cara Pembuatan Rencana Campuran Beton Normal (In Indonesian): SNI 03-2834-2000,” BSN, Indonesia, 2000, pp. 1-34.

[19] Badan Standarisasi Nasional, "Standar Nasional Indonesia Untuk Tata Cara Pembuatan dan Perawatan Benda Uji Beton di Laboratorium (In Indonesian): SNI 2493-2011," BSN, Indonesia, 2011, pp. 1-17.

[20] ASTM C 192/C 192M-95, "Standard Practice for Making and Curing Concrete Test Specimens in the Laboratory," American Society for Testing and Materials, USA.

[21] Badan Standarisasi Nasional, "Standar Nasional Indonesia Untuk Metode Pengujian Kuat Tekan Beton (Test method for compressive strength of concrete): SNI 1974-2011," BSN, Indonesia, 1990, pp. 1-15.

[22] Lea, F. M., "The Chemistry of Cement and Concrete," $3^{\text {rd }}$ edition, Edward Arnold Ltd, London, 1970, pp. 1-740.

[23] Badan Standarisasi Nasional, "Persyaratan beton struktural untuk bangunan gedung dan penjelasan (In Indonesian): SNI 2847-2019,” BSN, Indonesia, 2019, pp. 1-695.

[24] ACI 318M-14/318RM-14, "Building Code Requirements for Structural Concrete (ACI 318M) and Commentary (ACI 318RM-14)," American Concrete Institute, Farmington Hills, USA, 2015, pp. 1-519. 